\title{
It's Worse than "Reverse" \\ The Full Case Against Ultra Low and Negative Interest Rates
}

\author{
William White*
}

\section{Working Paper No. 151}

\author{
March 5 ${ }^{\text {th }}, 2021$
}

\begin{abstract}
It is becoming increasingly accepted that lowering interest rates might at some point prove contractionary (the "reversal interest rate") if lower lending margins cut the supply of bank loans. This paper argues that there are many other reasons to question reliance on monetary policy to provide economic stimulus, particularly over successive financial cycles. By encouraging the issue of debt, often for unproductive purposes, monetary stimulus becomes increasingly ineffective over time. Moreover, it threatens financial stability in a variety of ways, it leads to real resource misallocations that lower potential growth, and it finally produces a policy "debt trap" that cannot
\end{abstract}

\footnotetext{
* Chairman of the Economic Development and Review Committee, OECD. This paper is based in part on remarks made in the closing panel of a two-day conference at Imperial College Business School, London, on "The effects of ultra low interest rates on banks and the economy". The conclusions drawn in this paper are not necessarily shared by any of the institutions with which the author is currently or has previously been associated.
} 
be escaped without significant economic costs. Debt-deflation and high inflation are both plausible outcomes.

\section{https://doi.org/10.36687/inetwp151}

JEL codes: E40, E43, E44.

Key words: negative interest rates, yield curve control, financial stability, banking supervision, shadow banking. 
"For every complex problem there is an answer that is clear, simple and wrong."

H.L. Menken

\section{Introduction}

Concerns about the negative effects of "easy money" and ultra low interest rates in the advanced market economies (AMEs) were being expressed well before the crisis of 2008. ${ }^{1}$ The misgivings primarily reflected the fact that monetary easing had become, without adequate debate, the preferred countercyclical policy instrument in successive downturns (or feared downturns) since the middle 1980's.

These concerns only deepened with the onset of the Great Financial Crisis (GFC) in 2008. The aggressive monetary policies that followed were in part inevitable, given concurrent decisions to tighten fiscal policy and also financial regulation. Monetary policy was thus left as "the only game in town." However, the willingness to rely on monetary expansion also seemed to rest upon the untested premise that "more of the same" would ensure the strong, sustainable and inclusive growth sought by the G20. ${ }^{2}$ Indeed, this extrapolative logic was eventually used to justify the introduction and maintenance of negative policy rates in a number of jurisdictions even prior to the pandemic.

Since the onset of the pandemic in March of 2020, monetary easing in the AMEs has been pursued still more vigorously. In recent months, many Emerging Market Economies (EMEs) have also begun to join in, some using Quantitative Easing for the first time. Moreover, there is speculation that even more expansionary monetary policy (e.g., negative yields or yield curve control in the United States) might be warranted in the future. The fact that further monetary easing has been accompanied by a sharp increase in both government deficits and sovereign debt ratios has also raised new fears of "fiscal dominance" and much higher inflation. The assumptions underlying these aggressive monetary policies therefore warrant, indeed prudence demands, a closer look.

\footnotetext{
${ }^{1}$ See successive annual reports of the Bank for International Settlements dating back to the late 1990's. Also Borio and White (2004) and White (2006).

${ }^{2}$ There has not even been a serious discussion of the narrower question of whether CPI "price stability" is a necessary, much less sufficient, condition to ensure achievement of the G20 goals. While this is simply assumed by central banks, there is a rich pre-War literature advocating deflation as the optimal policy response in the face of rising levels of labor productivity. See Selgin (1997). Empirical studies also indicate that CPI deflations historically have not been generally associated with output losses much less deflationary spirals. See Atkenson and Kehoe (2004) and Borio et al. (2015). Finally, an impressive roster of ex central bankers has recently expressed serious reservations about relying on monetary policy to push inflation up to target levels. See de Larosiere (2019), Hannoun et al (2020) and Volcker (2018) An implicit sub theme is that more reliance might have been put on fiscal expansion instead.
} 
One set of concerns raised in the literature is that the effectiveness of monetary easing in stimulating aggregate demand might well be non-linear. Indeed, in the end, easing might even have the opposite effect to that desired. Recently, the concept of the "reversal interest rate", proposed by Koby and Brunnermeier, ${ }^{3}$ has received a great deal of attention. They focus on how lower rates squeeze bank lending margins and eventually the supply of credit. Their insights about how bank credit influences the effectiveness of monetary stimulus are important and essentially correct. However, it will be suggested in this paper that the non-linearity problem is much more fundamental, and it depends on the reaction of borrowers as much as lenders. There are far greater dangers than those suggested by the "reversal interest rate" alone.

There is a fundamental intertemporal inconsistency involved in the repeated use of monetary easing to stimulate demand in the AMEs. Initially, lower policy rates encourage private spending (households and corporates) to be brought forward in time, often with unproductive purchases (especially consumption) being financed by debt accumulation. Over time, however, as tomorrow becomes today, the weight of the debt burden accumulates and the effectiveness of further monetary easing declines. Moreover, there are other plausible reasons to doubt the effectiveness of monetary easing in stimulating aggregate demand. As Keynes (1961, p.173) remarked in the General Theory; "if, however, we are tempted to assert that money is the drink that stimulates the system to activity, we must remind ourselves that there may be several slips between the cup and the lip".

Another concern is that ultra low interest rates in AMEs can have a multitude of other undesired side effects, not least on financial stability in the AMEs, on potential growth in those economies and on the economic and financial stability of EMEs. Admittedly, none of these concerns seem to trouble those who rely on prevalent Neoclassical (DSGE) macroeconomic models, including many central banks. ${ }^{4}$ Yet, concerns about side effects that emerge only over time have surfaced repeatedly in the history of economic thought. They are central to the work of Minsky (2008) who reminded us that "stability breeds instability." Moreover, they resonate with the work of Hayek (1975) who emphasized the importance of "malinvestments" and the need to recognize "complexity" when considering the setting of monetary policy. At the very least, such considerations might help to foster greater humility among policymakers and temper their willingness to adopt ever more experimental policies ${ }^{5}$.

A final concern has to do with the exit problem. Each cycle of monetary easing contributes to a buildup of undesired side effects that raises the likelihood of future instability. Central banks are then lured into a "debt trap" where they refrain from tightening, to avoid triggering the crisis that they wish to avoid, but that restraint only makes the underlying problems worse. In effect, after

\footnotetext{
${ }^{3}$ For example, see Koby and Brunnermeier (2019). Lower policy rates lower bond yields and provide capital gains to banks but, as this wears off, bank capital and future lending is threatened by lower lending margins.

${ }^{4}$ This because the kinds of variables or considerations that might capture such concerns (e.g. debt, bankruptcy and a leveraged financial sector) are not included in their models.

${ }^{5}$ Grisogona (2020) describes computer simulations directed to finding effective AI solutions to identified problems in complex, adaptive systems. A fundamental shortcoming associated with bad decision makers is that they have a "low tolerance for ambiguity". Put otherwise, they think they know much more than they actually do.
} 
successive cycles, a debt-super-cycle emerges that threatens debt/deflation on the one hand, or significant inflation on the other.

The empirical evidence referred to in this paper is largely drawn from the years before the onset of the pandemic early in 2020. Particular emphasis is put on the effects of monetary policy measures during and after the beginnings of the GFC in 2008. What is argued here is that prepandemic monetary policy actually created economic "preconditions" that made the global economy highly susceptible to a downturn even before the virus arrived and social distancing began. The subsequent easing of monetary policy has made those preconditions worse, implying that monetary policy may now be at the point where it is doing more harm than good. ${ }^{6}$

The focus below is first on the effectiveness and side effects of ultra low but positive, nominal interest rates. Then some of the possible implications of introducing negative policy rates are considered. Finally, there is a brief assessment of alternative policies that might be more effective than easy money in ensuring a sustainable recovery from the current global recession.

\section{The Effects of Positive but Ultra Low Rates}

\section{a) Their effectiveness in stimulating aggregate demand in AMEs?}

As noted above, the biggest issue is an intertemporal inconsistency associated with the rising levels of global debt. In practice, the effectiveness of policy today reduces the likelihood of its effectiveness in the future, a feedback process once characterized as "headwinds" by Allen Greenspan. Far from declining in the aftermath of the crisis that began in 2008, the ratio of global debt (households, corporates and governments) to global GDP at the end of 2020Q1 was (according to the IIF) 50 percentage points higher than in 2008. In effect, the "headwinds" had already grown to gale force before the arrival of the pandemic. The biggest increases were in government debt ratios in AMEs and corporate debt ratios in EMEs and also the United States. Since the pandemic, the most worrisome developments have been sharp increases in AME corporate debt, of increasingly lower quality ${ }^{7}$, and further increases in the debt of lower income EMEs.

In the AMEs, it is a fact that the post-crisis recovery from the GFC was the weakest of all recoveries in the post War period. Moreover, in every year after the crisis (with one exception), the growth rate of GNP projected for the next year by the IMF and OECD significantly overestimated the actual outcome. Forecasts for inflation were similarly overestimated. Investment levels, which conventional models generally assume will be responsive to monetary

\footnotetext{
${ }^{6}$ Michael Woodford (2020) argued at Jackson Hole that the pandemic, by reducing income flows, has altered the ability to spend ("effective demand") rather than the desire to spend. He concludes "deep cuts in real interest rates are not really what is needed to deal with this kind of crisis". Alternatively, "there is instead a strong case for the use of fiscal transfers as a tool of stabilization policy. Since many AME's are now running double digit deficits, this and similar arguments for fiscal expansion have evidently proven persuasive.

${ }^{7}$ Not only have junk bonds taken an increasing share of corporate finance but, within that category, the proportion provided to the riskiest borrowers (triple C or below) rose by February 2020 to its highest level since 2007. See Rennison and Platt (2021). Similarly, the proportion of loans made with "covenant-lite" provisions rose from 20 percent of total, prior to the GFC, to 80 percent in 2018 according to the Financial Stability Board.
} 
stimulus, were particularly weak ${ }^{8}$. In the EMEs, growth after the onset of the GFC was relatively more vigorous but subsequently showed increasing signs of weakness as debt levels ratcheted higher.

In addition to the "headwinds" of debt, a number of arguments support the view that monetary easing might be less effective than many suppose. One possibility, affecting both consumption and investment, is that ever more experimental policies raise levels of unease among both households and corporations. This induces them to "hunker down" and to constrain spending rather than to spend more. Such a possibility is clearly consistent with the Keynesian invocation of "animal spirits" that are driven by psychological propensities.

Nor is it at all clear that lower rates should induce more consumer spending. If consumers have a predefined goal for wealth accumulation to ensure a comfortable retirement, then a lower rate of accumulation implies they must save more not less. ${ }^{9}$ Similarly, lower rates lower the disposable income of creditors (say older people living off investments) and raise the disposable income of debtors. If the former group has a higher marginal propensity to consume than the latter, aggregate consumption might actually fall. Finally, the argument that lower rates increase "wealth", and therefore induce more spending, seems to suffer from a fundamental analytical flaw. Lower rates provide accounting gains, but they do not create "wealth" if wealth is appropriately defined as the capacity to have a higher standard of living in the future. ${ }^{10}$ For example, higher house prices constitute an increase in "wealth" for homeowners only if you ignore the higher (implicit) cost of living in a house in the future. ${ }^{11}$ What is true is that higher house prices provide more collateral to support more borrowing, but that is a quite different thing.

There are similar arguments to support the view that capital investment might also fail to respond to ultra low rates. To the extent that future consumption is expected to be held back by the "headwinds" of debt, investment to meet demand might also be expected to be weak. ${ }^{12}$ Closely related, company pension schemes (defined benefits) are hurt by low rates and this can be a contingent liability weakening future cash flow and investment. Further, there is growing evidence that low rates encourage mergers and acquisitions and levels of corporate concentration. Absent an adequate degree of competition, there is no need to invest to strengthen one's competitive position. Finally, Smithers (2019) and Acharya (2019) both emphasize how low rates encourage corporate managements to cut investment and to borrow in order to raise cash to finance share buybacks. These purchases raise share prices and the value of share options

\footnotetext{
${ }^{8}$ In contrast, the empirical literature has tended to support the view that investment is more likely to respond to "accelerator" effects driven by rising effective demand.

${ }^{9}$ For an early argument of this sort, see Bailey (1962). This tendency will be reinforced if there is also uncertainty as to whether pension obligations will be honored. Sadly, this seems increasingly likely. The replacement of defined benefit plans by defined contribution plans, where the latter suffer if rates are low, adds to this uncertainty.

${ }^{10}$ See Merton (2006) and White (2006).

${ }^{11}$ In any event, the "wealth" provided by higher asset prices accrues in large part to richer segments of society that might be expected to have a relatively low marginal propensity to consume.

${ }^{12}$ After the Fed began lowering rates in early 2019, the growth rates of shipments of core capital goods and also of non-residential business investment continued to decelerate.
} 
owned by management, to their advantage. In contrast, the longer run interests of the corporation are not well served if the stock of productive capital does not expand.

Much academic attention has been focused how ultra low rates might affect the behavior of banks. Koby and Brunnermeier (2019) focus on squeezed margins and suggest that a "reversal interest rate" exists that, once breached, leads to expansionary monetary policy actually becoming contractionary. It occurs when capital gains, arising from duration mismatch as long rates fall, are overwhelmed by decreases in net interest margins. As capital constraints bite, banks cut loans. Evidently, the longer the reliance on monetary expansion, the greater the likelihood that this second force will prevail. In short, the "reversal rate" rises over time. Recent efforts by the Federal Reserve and the ECB to promote lower long rates seem to ignore such concerns. ${ }^{13}$ In contrast, the introduction of Yield Curve Control by the Bank of Japan was directed to keeping long rates up to help maintain intermediation spreads along with bank profits.

Other studies come to similar conclusions about the reality of the "reversal interest rate" effect, although they also point to the difficulties of being precise about when the effect kicks in ${ }^{14}$. When monetary easing is used to resist an economic downturn, Stehn and Radde (2019) have shown that the reaction of banks depends on their initial level of capital, which affects both their rate setting decisions and the willingness of depositors to withdraw deposits as the deposit rate is lowered. Similarly, Martinez-Miera (2019) has shown that the overall effect on credit expansion is dependent on the degree of competitiveness in the banking industry as well as the capacity of non-banks to provide substitutes for bank credit.

One particularly important issue is how initial capital levels affect lending decisions as (if) margins shrink when policy rates are lowered. Acharya et al (2020) argue that when initial capital levels are low ("weak" banks), banks tend to "evergreen" old loans thus creating "zombie" companies. Preoccupied with managing these legacy assets, they also cut back on making new, risky loans. In effect, the "reversal rate" for weakly capitalized banking systems is high, as is the risk that ultra easy monetary policy might have effects contrary to those intended. These risks are compounded (discussed below) when the effects of "zombies" on the real economy are considered.

Nor can it be concluded that higher capital levels adequately deal with these dangers. Banks with still high levels of capital ("strong" banks) after the GFC did respond positively to the stronger demand for credit encouraged by lower rates. But, as a result, virtually every country that retained a strong banking system (Canada, New Zealand, Australia, the Nordics and others) had record high ratios of mortgage debt to household income as well as record high house prices

\footnotetext{
${ }^{13}$ A commonly heard argument is that lower rates, both short and long, are "effective" in stimulating spending in spite of the "reversal interest rate" effect. Of course, the arguments put forward in the preceding text imply this might not be the case.

${ }^{14}$ Turning to monetary tightening in the face of excessive credit expansion, Barlevy (2019) has suggested that it could be effective or non-effective depending on how it was done. In short, drawing simple conclusions about how banks react to changes in the stance of monetary policy is very difficult.
} 
when the pandemic struck. There is widespread concern in each of these countries that these developments might trigger future instability.

Finally, it should be noted that not all the empirical evidence supports the proposition that capital ratios and lending are positively correlated. Banks in Europe are generally thought of as "weak", and might therefore have been expected to cut back on lending as monetary easing further squeezed their profit margins. However, a recent report from the European Banking Authority ${ }^{15}$ suggests the opposite by noting that European banks were aggressively investing in commercial real estate and loans to small business prior to the pandemic. This could of course have been be a form of "gambling for resurrection", which also implies potential problems going forward. At the same time, there was also a very significant increase in European corporate borrowing through bond markets, just within investment grade and often covenant-lite. This also suggests that ultra low rates might have contributed to imprudent borrowing as well as lending. Since the pandemic, loan growth in Europe (and in some other countries as well) has also been supported by government loan guarantees.

\section{b) The unintended side effects of ultra low rates in AMEs?}

The first side effect to consider is the possibility that ultra low rates might threaten the stability of the financial sector. This could happen in a variety of ways. The stability of financial institutions could be put at risk. Financial markets could also experience inflated prices, and the prospect of subsequent collapse, as well as bouts of market malfunctioning and even closure. Funding liquidity problems could bring other problems in train. Finally, it must be recognized that problems of one sort often trigger other problems with potentially systemic implications.

If margins are being squeezed, as most evidence seems to indicate, the business models of many financial institutions could become threatened. Pension funds and insurance companies are most at risk since they have long liabilities, which rise as rates fall, and are already facing problems arising from changing demographics. "Funding ratios" of pension funds are falling virtually everywhere, with the decline at US State and Local Pension funds being particularly severe. ${ }^{16}$ As described above, the effect on banks is likely to be substantial, if less severe. Already threatened by the nascent Fin Tech industry, employment at banks has declined sharply in recent years ${ }^{17}$. Further, the ratios of market value to book value for European and Japanese banks were at record lows prior to the pandemic. A related concern is that lower profits at banks (especially in Japan and Europe) will constrain needed investments in technology, not least to update old and legacy systems and to counter cyber threats.

Not surprisingly, both pension funds and insurance companies have in recent years sharply expanded the purchase of alternative financial instruments in the "search for yield", with the most underfunded doing so most aggressively. Similarly, Japanese regional banks and insurance

\footnotetext{
${ }^{15}$ See the description by Binham (2019).

${ }^{16}$ The ratio declined from 102.7 percent in 2000 to 72.8 percent in 2018 in spite of (likely) unrepeatable capital gains on both bonds and equities.

${ }^{17}$ Recent estimates indicate the loss of 60000 jobs in European banking since the crisis began.
} 
companies have invested heavily in risky Collateralized Loan Obligations issued in dollars. ${ }^{18}$ The Global Financial Stability Report of the IMF (2019) documents how pension funds, insurance companies and asset managers have taken on riskier and less liquid assets. It then goes on to speculate about the possible economic impact should some of these risks materialize. Most alarmingly, IMF simulations suggest that a recession half as severe as 2009 would result in \$19 trillion of corporate debt having been issued by companies whose debt service requirements exceeded their shrunken profits. The knock-on effects on financial institutions that have purchased such assets could be significant.

Closely related, the same IMF Report expresses concern that a combination of low yields and tighter financial regulation of banks has been pushing borrowing into less regulated sectors. There has been a sharp increase in the reliance on financial markets for funding, especially by corporate borrowers, and the reliance on direct lending by private equity firms has also increased. As well, the Financial Stability Board (2020) recorded a steady increase in the share of total financial assets held by non-bank financial institutions between 2008 (42.0 \%) and 2019 $(49.5 \%)$, with many of those institutions considered to pose bank-like financial stability risks. In the United States, the proportion of mortgages initiated by non-banks rose from $9 \%$ in 2009 to $44 \%$, while the proportion of mortgages serviced by non-banks rose from $5 \%$ to $41 \%$. ${ }^{19}$ While the Financial Stability Board (2017) believes that the "shadow banking" problems that materialized during the GFC have been dealt with, these ongoing structural changes imply that other problems might have emerged in the non-bank ("shadow bank") financial sector. ${ }^{20}$

Low policy rates (and other unconventional monetary measures) have also contributed to higher prices for financial assets. Early in 2020, prior to the pandemic, around \$17 trillion of sovereign bonds offered negative yields, while corporate spreads (over sovereigns) were also exceptionally low, especially for bonds just above or below investment grade. The unusually high price of US equities and the low value of the Vix were also notable. For example, in early January 2020, the Shiller PE ratio (CAPE) was around 31, almost double the historical median ratio of just less than 16. Finally, as noted above, in many countries house prices were at historical highs when the pandemic struck.

The fact that equity prices continued to rise (indicating expectations of high growth?) prior to the pandemic, even as bond rates fell (indicating expectations of low growth?) testified to the overwhelming influence of central bank liquidity. ${ }^{21}$ Investors were buying low or even negative yielding sovereign debt in anticipation of further rate declines with associated capital gains. ${ }^{22}$ In

\footnotetext{
${ }^{18}$ There is some evidence that this has been officially encouraged to help reduce the value of the Yen. One danger is that the short-term sources of dollar funding, used to finance long-term investments, dry up and cause a dollar liquidity shortage. This is what happened to a number of European banks at the beginning of the GFC, leading to a reactivation of dollar swap lines by the Federal Reserve.

${ }^{19}$ See the worries expressed by McWilliams (2018), then head of the US Federal Deposit Insurance Corporation.

${ }^{20}$ For a more extended discussion see White (2020).

${ }^{21}$ Historically, Treasury yields and equity prices have had a positive correlation, not a negative one. Similarly, Treasury yields and corporate spreads have historically had a negative correlation as stronger growth leads to higher Treasury yields and reduced expectations of corporate failures. This correlation also turned positive as central bank liquidity supported all prices.

${ }^{22}$ As yields fall, the capital gains (in percentage terms) associated with a given change in basis points increases.
} 
effect, investors seem to have been betting on being able to sell these bonds to some "greater fool", perhaps even to the central banks. Similarly, the willingness of private investors to buy equities and other risky assets, even when equity prices appeared high by traditional metrics, indicated a belief that they might rise even higher. The question raised by these developments was what might happen when this overt speculation stopped or even went into reverse? ${ }^{23}$ There were fears that the scope for disorderly outcomes might be substantial.

These concerns materialized when the pandemic hit and many prices fell very sharply. However, their subsequent rebound showed the continuing power of central bank intervention. The prices of virtually all financial assets rose sharply and steadily after the initial central bank interventions in March 2020, then moderated somewhat, and then advanced even more quickly near the end of 2020. As new vaccines raised the possibility of an end to lockdowns and faster economic growth, private borrowers rushed to lock in financing at low rates. Central banks (especially the Fed) further encouraged this price rebound by repeating that policy rates would stay low for an extended period, even if inflation were to rise temporarily. ${ }^{24}$

To be more specific, risk free bond rates continued to fall over most of this period. As a result, the average yield on junk bonds fell to 3.9 percent in late February 2021, versus a previous low of 6.8 percent prior to the GFC. Stock markets also hit record highs with retail investors being particularly active. Indeed, their use of call options to push up the prices of favored stocks ${ }^{25}$ was historically unprecedented. Similarly, there was an unprecedented increase in the listing of Special Purpose Acquisition Companies to raise cash to merge with (and effectively list) promising but unlisted companies. ${ }^{26}$ Not surprisingly, these developments (increasingly referred to as the "everything bubble") again raised the question of sustainability in the light of underlying economic fundamentals. ${ }^{27}$

Other concerns about the stability of the financial sector, this time linked to disorderly market outcomes, also increased as signs of market malfunctioning multiplied. Following the onslaught of the 2008 crisis, waves of Risk/On-Risk/Off behavior were driven by changes in central bank policies. This implies that the potential gains from diversification and value investing were both lost. Liquidity declined in many markets, with particular concerns being expressed about prospective illiquidity in corporate debt markets (especially for currently rated BBB securities)

\footnotetext{
${ }^{23}$ At some point, the "greater fool" argument must lose its allure.

${ }^{24}$ The Fed's new monetary policy framework emphasizes the need to restore "maximum employment" and puts a new focus on "average inflation" This will allow inflation overshoots to compensate for past undershoots.

25 This was facilitated by new platforms like Reddit and Robinhood. Retail investors were strongly involved in the exponential price increase, and then collapse, of the stock of GameStop in early 2021. Its price rose over twentythree times in only eleven days. This and similar developments prompted the Centre for Financial Stability (2021) to raise questions about the implications of these developments for systemic stability and financial regulation going forward.

${ }^{26}$ This raised a variety of concerns. In addition to worries that companies might become listed without effective due diligence, it was worrisome that promoters of these deals often made huge up-front profits before the acquired firms showed that they were in fact profitable.

${ }^{27}$ See BIS (2020 p.1) who note "This raised questions about whether risky asset prices had disconnected from the underlying economic outlook". The Financial Times was also motivated to assemble a series of twelve articles called "Runaway Markets". The title says it all.
} 
should they be subject to a downgrade. Moreover, the process of "price discovery" atrophied; in Japan, whole days went by without private sector trades in government bonds. Further, recurrent "flash crashes" and enduring market anomalies ${ }^{28}$ also indicated that markets were not functioning as they should.

The Fed's temporary loss of control over the US repo rate in September 2019, and the ad hoc measures taken in the following months to avoid similar developments, strongly suggested that some combination of ultra low rates and changes in financial regulation ${ }^{29}$ had had unintended consequences. Structural changes (the expansion of passive trading, reliance on Exchange Traded Funds and the growing use of algorithmic and high-speed trading) added to the uncertainty about future market functioning and the possibility of disorderly market developments. The market turmoil in March of 2020, highlighted by illiquidity in the market for US Treasuries, ${ }^{30}$ provided further dramatic evidence that these worries were justified. Unprecedented intervention by central banks, effectively acting as "market makers of last resort", did stabilize markets. However, it also aggravated significantly the concerns about market functioning referred to above. ${ }^{31}$

Finally, following the GFC, the search for yield drove many asset management companies into more illiquid investments, while they still offered same day redemptions to clients. Should redemptions increase and funding liquidity problems arise, the worry was that "fire sales" might then become both more common and more brutal. Questions were also raised as to whether pension funds and insurance companies would be able to play their normal stabilizing role (buying on the dips) when they too had fewer liquid assets on hand. The market turmoil in March 2020 indicated that these concerns were also not baseless.

Liang (2020) documents how, in March 2020, the acceleration of large redemptions from investment grade corporate bond mutual funds put downward pressure on the prices of investment grade corporate bonds. Indeed, the market dysfunction associated with this episode was as great as for high yield bonds. Similarly, withdrawals from ETF's led to sales of the underlying assets and raised the prospect of an "illiquidity doom loop" in bond prices and the collapse of some ETF's ${ }^{32}$. To calm the market, the Fed felt the need for unprecedented interventions, including the purchase of ETF's containing bonds recently downgraded to "junk" status. As noted above, the stability provided by these interventions allowed corporations (including many that were already highly leveraged) to issue still more bonds to raise cash to tide

\footnotetext{
${ }^{28}$ Not least, the theorem of covered interest parity was consistently violated after 2008 . This implied that those seeking to obtain US dollars through the swap market in the future might well find themselves disappointed. This raised in turn the question of whether the Fed would then come to the rescue as it did in 2008 and 2009. Fortunately, the Fed did extend its US dollar swap lines in March of 2020, though only to a limited number of the EMEs facing potential problems.

${ }^{29}$ Attention has increasingly focused on the attempts of systemically important US banks (G-SIBs) to manage their balance sheets at quarter and year ends to reduce future regulatory capital requirements.

${ }^{30}$ Schrimpf et al (2020)

${ }^{31}$ See Allaj and Platt (2021)

${ }^{32}$ See Chappatta (2021)
} 
them over the period of the pandemic. Liang notes that the Fed's actions were highly successful, but at the price of a significant increase in moral hazard. ${ }^{33}$

Another issue is the unintended effects of easy money on the supply side of the economy; i.e., the level and growth rate of potential. It is well known ${ }^{34}$ that "busts" after a financial/credit "boom" tend to be deep and long lasting. Cerra and Saxena (2008) even suggest the losses are never fully recovered. Indeed, in a later paper, ${ }^{35}$ they suggest that "all recessions... not just those associated with financial and political crisis.... lead to permanent output losses". Given that downturns do seem to affect permanently the supply potential of the economy, they conclude that "Economic policies should be geared towards avoiding crises and severe recessions and responding with appropriate stimulus and safety nets." In short, policies that "lean" against costly booms should be considered along with policies that "clean" up afterwards. What, perhaps, has been given too little consideration is the possibility that monetary policies intended to "clean" up afterwards might also have negative effects on potential output. If so, this would reinforce the argument for "leaning" in the first place. ${ }^{36}$

In recent years, there have been a number on investigations into this supply side issue, following on work done earlier. ${ }^{37}$ BIS research ${ }^{38}$ documents how low productivity growth sectors (in construction and retail especially) were encouraged to expand during the boom preceding the GFC. Further, during the bust, companies in these sectors received "evergreen" loans from their banks which sustained them as "zombie" companies. ${ }^{39}$ Banks do this because low interest rates reduce their financing costs, and because they have doubts about their own solvency (or have concerns about market reactions) should they instead classify these loans as non-performing. These unwelcome practices have also been documented by the OECD, the IMF and others. ${ }^{40}$ The IMF has been particularly concerned about regulatory forbearance which has allowed such practices to continue.

The concern about "zombie" companies is perhaps highest in Europe, but concerns extend to other countries including the United States. ${ }^{41}$ The willingness of bond markets, searching for yield, to extend credit under increasingly favorable terms to firms with doubtful future prospects compounded the "zombie" problem even before the pandemic. The sharp reduction in corporate default rates in recent years also attests to the growing zombification of many economies. Since

\footnotetext{
${ }^{33}$ She was not alone in expressing this concern. For example, see Tepper (2020) who writes "The obvious beneficiaries of the junk bond-buying programs are overleveraged private equity groups and unhealthy borrowers... Investors and chief executives are learning that no matter how imprudent their behavior in good times, when the bad times inevitably arrive, they will be thrown a lifeline".

${ }^{34}$ Reinhart and Reinhart (2010)

${ }^{35}$ Cerra and Saxena (2017)

${ }^{36}$ This shift in emphasis would seem broadly consistent with the insights of Hayek.

${ }^{37}$ A perhaps seminal article was that of Peek and Rosengren (2005).

${ }^{38}$ Borio et al (2015). Also, Banerjee and Hofmann (2018) and Doerr (2020).

${ }^{39}$ Definitions of zombie companies vary. The OECD studies define them as "old firms (i.e. 10 years or above) that cannot cover interest payment with their profits over three consecutive years."

${ }^{40}$ See OECD (2017) which contains a long list of the many studies carried out at the OECD in conjunction with work done at Working Party 1. See also IMF (2017), Acharya (2020) and Borio et al (2015)

${ }^{41}$ Bloomberg News Wire (2020) and Lynch (2020).
} 
the pandemic, the drawing down of bank lines and heavy recourse to bond markets has likely made this problem worse. Insolvencies have in fact declined further in many countries.

Acharya et al (2020) document how the process works, using a huge European company data base. ${ }^{42}$ In sectors where zombie firms prevail, prices decline (as do profits) reflecting the increase in competition in product markets. However, increased competition for factor inputs raises costs and further decreases profits for all. This reduces investment, particularly for healthy firms, and decreases the growth in future productivity. The level of productivity in the sector also falls arithmetically since it includes low productivity zombies. In short, zombies increase disinflationary pressures in the short run, since excess capacity is maintained, but they also lower the level and the growth rate of productivity. Put otherwise, zombification encourages (through lower inflation) further monetary stimulus even as it raises the probability of future inflation. ${ }^{43}$

Moreover, since the GFC, it has become increasingly apparent that ultra low interest rates (and other aspects of monetary easing) have had other negative effects on productive capacity as well. Easy financing diverted real resources towards "unicorns", many of which seem destined never to make an adequate rate of return. The negative market reactions to recent IPOs at We Work, Lyft, Uber and other such companies has indicated a growing recognition of this possibility. ${ }^{4}$ Moreover, as such firms subsidize their products, in search of market share and eventual monopoly, they also contribute to disinflation which raises the likelihood of a rebound once such practices stop. Finally, ultra low rates favor increased industrial concentration and the exercise of industrial power. The purchase of innovative new companies by incumbents seems sure to lower innovation over time.

A third set of worrying side effects of ultra low interest rates in AMEs has been the spillover into emerging market economies (EMEs). The increase in global debt ratios after 2008 was almost wholly due to an expansion in debt in EMEs. The overall EME debt ratio rose from 110 percent in 2008Q3 to 230 percent in 2020Q1. Chinese household debt (as a \% of GDP) doubled after 2012 to reach 60 percent, surpassing the 50 percent in Europe. Moreover, the IMF (2019) observed that 40 percent of low-income countries were either "in distress" or at "high risk" of debt distress, well before the pandemic crisis. To put this another way, the debt ratio of the lowincome countries had risen back to levels seen prior to the most recent episodes of debt forgiveness. In light of the pandemic crisis, another round of debt forgiveness now seems even more necessary, but it will not be easy to achieve..$^{45}$

Since cross border flows to EMEs are only a small part of total cross border flows, marginal changes in AMEs can have big effects on EMEs. ${ }^{46}$ Relatively easy money in AMEs led to capital inflows to EMEs almost continuously from 2004 to 2014, interrupted only by the crisis itself.

\footnotetext{
${ }^{42}$ The data base covers 1.1 million firms in 12 countries and 65 sectors. The data runs from 2010 to 2017.

${ }^{43}$ The pandemic has obviously lowered both aggregate demand and aggregate supply. The sharp easing of monetary policy presumes that the effects of the former are greater than those of the latter and that the overall effect will be disinflationary. Concerns about future inflation will be greater if this assumption is proved false.

${ }^{44}$ Many other firms of long standing have yet to make profits or have only just begun to do so.

45 The need and the obstacles are well outlined in Bulow et al (2020).

${ }^{46}$ Cavallino (2019) also provided evidence in support of the existence of "spillovers".
} 
However, these flows also ebbed and flowed from 2004 until 2020 in response to the waves of Risk/On and Risk/Off behavior. Since the onset of the pandemic, and the demand stimulus provided by both central banks and governments, the Risk/On environment has further encouraged a significant increase in capital inflows into EMEs and a sharp rise in domestic asset prices.

In spite of increased recourse by EMEs to capital flow management (increasingly accepted by the IMF) and growing use of macroprudential instruments, there was upward pressure on EME exchange rates prior to 2015 and sporadically since. Upward pressure has been strongly resisted throughout by FX intervention (raising bank reserves in domestic currency) and easier monetary policy than otherwise. Domestic credit expansion rose sharply, funded by both domestic and foreign sources, and the EMEs have increasingly shown many of the unintended consequences seen in the AMEs and described above.

Not least, significant threats to financial stability in EMEs have arisen. The migration of domestic lending to non-banks ("shadow banking") in both China and India is now a source of major concern. The McKinsey Global Institute (2019) has recently documented how risky corporate lending has exploded, with interest coverage of less than $11 / 2$ for $37 \%$ of Chinese loans, and for $43 \%$ and $32 \%$ of Indian and Indonesian loans respectively. ${ }^{47}$ Property developers and SOEs (often concentrated in oil and gas extraction and mining) are prominent borrowers, even though their internal rates of return have been falling. ${ }^{48}$ Finally, much of the EME corporate debt is denominated in dollars which leaves them vulnerable to counterparty risk (as the US dollar rises) as well as liquidity risk if maturing loans cannot be easily rolled over in dollars.$^{49} \mathrm{In}$ short, whereas in 2009 EMEs were part of the global solution to the global crisis, by the beginning of 2020 they had become part of the problem. The IMF (2019) and UNCTAD (2019) seem to agree that "push me" factors (low yields) in the AMEs were largely responsible for these unwelcome developments.

Finally, but briefly, three other side effects stand out. First, ultra low rates since the GFC have had distributional effects with political implications that go far beyond their economic implications. In particular, they have raised the value of financial and real assets that belonged disproportionately to the already wealthy. It is an empirical issue as to whether the gains in employment, particularly of the less well off, more than fully offset this distributional side effect $^{50}$ as many central banks have contended. Second, central banks policies have crossed the line into fiscal policy (through quantitative easing) and into regulatory policy (through macroprudential interventions). This will threaten central bank "independence" going forward,

\footnotetext{
${ }^{47}$ Commenting on the problems of Indian telecom firms, the Economist (2019) recently stated "If either firm (Bharti Airtel and Vodaphone) collapsed, India's fragile banks would be stuck with a Ghats-worth of non-performing loans".

${ }^{48}$ This problem could worsen as climate change mitigation "strands" many assets.

${ }^{49}$ When EME currencies were rising, it seemed to make sense to borrow in dollars since these labilities were declining in terms of domestic currency. However, this judgment implicitly assumed that the appreciation of their currencies would continue. Since 2015 the opposite has happened for most EME currencies.

${ }^{50}$ If the effectiveness of monetary easing declines over time, then there is less of a positive offset to the negative distributional implications.
} 
not least because it increases the chance that central banks will be blamed should economic prospects deteriorate for whatever reason. Third, and perhaps most important, ultra low rates and other monetary interventions have lowered government debt service ratios. This has encouraged governments to believe that the economic situation is under control, and that governments can also continue with "business as usual". This is becoming increasingly dangerous since the underlying problem is increasingly one of excessive debt at the global level, both public and private. The pandemic is now likely to reveal that we have an insolvency problem that only governments, not central banks, can deal with.

\section{c) Ultra low rates and the "exit" problem}

The positive effectiveness of monetary policy in stimulating demand declines with time. In contrast, the importance of the negative side effects rises with time. At some point, the latter exceed the former and a central bank might well feel that it should reverse a policy that is doing more harm than good. Unfortunately, there is a complication. One cannot simply ignore all of the implications of the original policy stance. In particular, the build up of debt encouraged by easy money leads directly to a "debt trap". ${ }^{51}$ As central bankers become increasingly aware of the need to renormalize monetary policy, to reduce the undesirable side effects, they become increasingly fearful that doing so will trigger the crisis they wish to avoid. Indeed, there are many historical precedents supporting such fears, including the German financial crisis of 1931 and bank failures in the Great Depression in the US. Central bankers should recognize that dealing with this problem is the number one challenge they face today.

Far from carefully tightening policy, both the Federal Reserve and the European Central Bank were easing policy prior to the onset of the pandemic. This occurred in spite of a strengthening economy and further declines in unemployment. One possible explanation is that this was a last, desperate attempt to put off into the future a debt crisis known to be building up under the surface. In contrast, and much more likely, it could be that both actions were driven by the persistent undershooting of inflation targets, a growing belief that the unemployment rate underestimated the amount of slack in the economy, and a persistent underestimating of the undesirable side effects of their own policies.

Whatever the motivation, the undesirable side effects of ultra low rates are now being encouraged still further. The dangers arising from this policy were well summarized by the late Paul Volcker in his recent autobiography. He said "Ironically, the "easy money' striving for a 'little' inflation as a means of forestalling deflation, could, in the end, be what brings it about." 52 The arguments presented in this paper concur with Volker's conclusion. These arguments suggest that a debt-deflation process of the type suggested by Irving Fisher (1933) is plausible, perhaps even likely, as a medium-term outcome. However, this does not rule out an inflationary outcome, either over the near-term or the long-term. As debt levels rise, the path to sustainable

\footnotetext{
${ }^{51}$ For a fuller list of the various economic and political factors inhibiting a "renormalization" of interest rates, see The Group of Thirty (2015) pp 43-44.

${ }^{52}$ Volcker (2018) p.227. Also see Hannoun et al (2020).
} 
real growth grows narrower and a traveler could fall off on either the deflationary or inflationary side.

Near term, the inflationary dangers are more evident. The promise of vaccines and the end of fear about serious infection could spur a rebound of demand that outstrips supply, itself shrunken by the pandemic and the effects of lockdown. Given government support measures in most AME's, personal saving rates have risen and the growth rate of monetary aggregates has recently been exceptionally high. The likelihood of still more fiscal stimulus, in the United States in particular, ${ }^{53}$ and of stronger spending on infrastructure in the near future, seem sure to aggravate those inflationary tendencies. Indeed, by late February of 2021, inflation expectations in the US (measured by breakeven yields) were already up one full percentage point over the previous year. Should this inflationary outcome materialize, the "debt trap" considerations discussed above imply that central banks will not react in a timely way ${ }^{54}$ and these inflationary pressures will be allowed to gain momentum. Eventually, either long bond rates will rise significantly, or policy rates will rise sharply, or both. Given the existing debt overhang, and the other exposures discussed above, these developments would trigger another sharp downturn and a return to the debt/deflation process expected as a central tendency. ${ }^{55}$

Even if this near-term scenario does not unfold, inflationary pressures could still emerge longerterm. A number of prospective, negative supply shocks can already be identified which will lead to both lower growth and higher inflation. The costs of climate change, whether the cost of mitigation or adaptation, will weigh heavily on future growth. As well, Goodhart and Pradhan (2020) emphasize global demographic shifts that lead to fewer workers and more elderly consumers; in effect, less supply and more demand. Finally, while particularly hard to predict, geopolitical forces and a growing emphasis on corporate "resilience" 56 could also disrupt global supply chains and the "efficient" production associated with them. All of these forces threaten a longer-term stagflationary future.

In the longer run, as Milton Friedman famously said, "inflation is always and everywhere a monetary phenomenon". The fundamental question then is how central banks will react to slower growth, whether associated with deflation (debt/deflation) or with inflation (stagflation). If they react by constantly trying to double down on monetary expansion, in effect refusing to "exit", the eventual effect is likely to be much higher inflation..$^{57}$ The likelihood of this happening will be

\footnotetext{
${ }^{53}$ Larry Summers (2021) and Olivier Blanchard (2021), both inclined to support fiscal stimulus, have warned that the Biden stimulus plan (of $\$ 1.9$ trillion), in addition to the previous Trump fiscal package, will seriously aggravate inflationary tendencies.

${ }^{54}$ Recently announced changes to the monetary policy framework in the United States further support this conclusion. Targeting "maximum possible employment", along with an "average" inflation rate over time, both provide room to avoid raising policy rates.

${ }_{55}$ An associated possibility is that central banks might try to lean heavily against prospective increases in bond yields. This might succeed, ushering in a period of "financial repression" in which rising inflation was not matched by rising rates. Over time, this would reduce the real burden of debt. This is discussed further below. However, another possibility is that such central actions would exacerbate rising inflationary expectations, bringing forward in time the problems described below as "longer term".

56 This has in fact been a welcome change induced by the pandemic. Efficiency is important but it is not everything. ${ }^{57}$ White (2016) and Acharya (2019) refer specifically to the problem of "zombie companies" causing slower growth. What if that slower growth triggers even more monetary easing and then even more zombies? Then, as White (2016,
} 
significantly increased if government deficits and debt are also rising simultaneously. In this case, fears of "fiscal dominance" can arise, often quite suddenly, leading to downward pressure on the exchange rate and eventually much higher inflation. How this works in theory has been well described by Sargent and Wallace (1981). Bernholz (2006) describes how, historically, it has all too often worked in practice.

\section{The Effects of Negative Interest Rates}

One possibility is that negative rates affect the banks and the economy in a similar way to successively lower, positive interest rates. In this case, all of the above analysis still applies. ${ }^{58}$ Negative rates are simply an extension of the "more of the same" policies that central banks have been following for many years now. However, another logical possibility is that there is something special about negative interest rates. They could result in a "phase shift" (as water turns to ice) where the effects of policy become strikingly different. A sudden change in the psychology of economic agents could account for such a shift.

Logically, it is possible that the "phase shift" is desirable; negative policy rates become more effective and also have fewer unintended consequences. Smets (2019) argues in support of the first proposition. He notes that the imposition of negative rates on bank reserves by the ECB proved to the market that negative rates were "possible" and that this triggered the sharp downward movement in longer term rates in the eurozone. This is plausible, though it still leaves unanswered the question of whether such lower rates do indeed spur more spending. As for the unintended consequences of monetary easing, no one has thus far suggested that they might be reduced below the zero bound.

It seems more likely that the "phase shift" will be undesirable; negative rates become less effective and have more unintended consequences. This would be consistent with the very cautious recourse to negative rates, by those central banks that have introduced them, and also the decision by other central banks not to introduce them. ${ }^{59}$ The decision of the Swedish Riksbank to raise previously negative policy rates back to zero also seems consistent with that view. It is notable that the Swedish decision came at a time when Swedish unemployment had risen, was expected to rise further, and when the household saving rate had already reached a local high. These are circumstances in which monetary easing might have seemed appropriate, yet the Riksbank did the opposite. It is also relevant that the Riksbank had been worried for some time about rising house prices and record high levels of household debt, the unintended consequences of previous easing. ${ }^{60}$

\footnotetext{
p192) puts it "the possibility of a vicious downward spiral is clear." Acharaya (2019, p2) expresses the same concern "These effects then lead to a cul de sac problem for accommodative monetary policy... The central bank ends up essentially trapped by its own past errors or miscalculations in having been ultra-accommodative."

${ }^{58}$ Using the analytic framework of Koby and Brunnermeir (2019), the "reversal interest rate" could be either negative or positive. There is nothing magic about zero.

${ }^{59}$ Most notably, the Chairman of the Federal Reserve has said "Negative interest rates is probably not an appropriate or useful tool for us in the United States." Senior officials at the Bank of Canada and the Bank of England have said there is no intention to introduce negative rates but have not ruled out the possibility.

${ }^{60}$ Indeed, the Swedish authorities had also revealed their concerns by tightening a number of macroprudential instruments.
} 
In assessing the effectiveness of negative policy rates in stimulating aggregate demand (via lower bank lending rates), the analytical framework is essentially that of Koby and Brunnermeier (2019) with an added constraint. A common assertion has been that negative policy rates put a particular squeeze on bank lending margins since banks are reluctant to lower deposit rates below zero. Indeed, it has been noted that negative policy rates might actually lead to higher lending rates as banks sought to restore margins. ${ }^{61}$ Somewhat short of this assertion, Eggerston et al (2017) "document a collapse in pass through to deposit and lending rates once the policy rate turns negative." In a separate study, Eggerston and Summers (2019) provide evidence from Sweden that also "suggests diminishing returns on interest rate cuts at negative rates."

A fundamental empirical question is whether banks are in fact reluctant to lower deposit rates below zero. One concern they might have is that negative rates will cause depositors to withdraw cash and then protect it using the services of cash custodians. A recent study for the ECB by Altavilla et al (2019) says that European banks have passed on lower rates to depositors, and that neither corporations nor households have increased cash withdrawals. Moreover, the study contends that corporations affected by negative rates have actually increased investment as intended. However, an important caveat is raised in the conditional conclusion drawn in the ECB study; "when banks are sound, the NIRP can provide stimulus to the real economy." Strong banks can reduce deposit rates below zero, knowing that depositors will not flee to weaker banks. However, weak banks do not have this luxury and engage in the evergreening of loans that leads to less investment, not more.

Should withdrawals of cash become a problem, countermeasures might also be put in place. Agarwal and Kimball (2019) argue that "administratively small actions by the central bank" could help in "enabling deeply negative rates". However, others ${ }^{62}$ have suggested that it might in fact be necessary to withdraw all notes from circulation, or at least high denomination notes. Still others suggest, as did Gessel in the pre-War period, that the introduction of "stamped currency" that lost some value each period might be the answer. Keynes ${ }^{63}$ also observed that "The idea behind stamped currency is sound" but then added "There are many difficulties which Gesell did not face." In this, he was referring to the possibility of substitution into possible near money, a possibility which has grown much larger today given modern technology. The growing interest by central banks in the possibility of issuing Digital Central Bank Currency has been driven, in part at least, by the perceived need to find ways to make monetary policy more effective when interest rates are already very low.

\footnotetext{
${ }^{61}$ In the immediate aftermath of the Swiss National Bank imposing a negative rate on bank reserves, Credit Suisse raised mortgage rates. Rates on credit cards have also been rising in the US. Looking further back in time, Keynes (1961, p.208) was well aware of the need for margins to cover the "intermediate costs of bringing the borrower and the ultimate lender together." He concludes "the rate of interest which the typical borrower has to pay...may be incapable of being brought ... below a certain minimum figure."

${ }^{62}$ See Rogoff (2016)

${ }^{63}$ Keynes (1981) p. 357.
} 
As for the possibility that the unintended consequences of negative rates might rise in a nonlinear way, there has been little serious discussion beyond a vague sense of uneasiness, ${ }^{64}$ largely focused around financial stability issues. One source of concern has been the recognition that most pricing models (like Black-Scholes) assume a positive, riskless rate and that negative rates usher in a totally uncertain environment. Another concern is that a traditional 60/40 (equity/bond) portfolio split loses its automatic hedging properties when bond rates fall to zero or below. In a recession, declines in equity prices are offset by increases in the price of bonds as interest rates fall. At or below zero interest rates, the scope for still further rate declines narrows. This raises the issue of how these previous hedges might be replaced and what attendant risks might arise in consequence.

It has also become clear that there can be political complications arising from negative rates. In many countries (especially in central Europe) saving and debt accumulation are moral issues. Negative rates punish "good" savers and reward the "bad" people who have taken on excessive debt. They could also be perceived as another effort to bail out the banks, in addition to all the support they received during the GFC. Such perceptions might further raise public anger as well as political tensions, not least a resurgence of nationalist populism.

Closely related, central banks that set negative rates could be seen as irresponsible. This could lead to calls for more democratic accountability and less central bank "independence". Similar sentiments were raised in the UK by Walter Bagehot, late in the $18^{\text {th }}$ century, when he said "John Bull can stand anything, except two percent." A recent publication by the Swiss Banking Association (2019) suggests that negative rates also send the message that "crisis" has now become a "permanent condition". The report stresses that such a change in perception is fundamental (a "phase shift"?) and this possibility should invite further consideration of whether negative policy rates might have unintended consequences, both economic and political.

Finally, de Larosiere (2019) raises the possibility of unintended consequences at the international level. Is it possible that negative rates could become an instrument used by central banks to depreciate their currencies, or to prevent them from rising $9{ }^{65}$ Could we have (or, indeed, have we already had) an undisclosed "currency war" that could exacerbate the economic costs of ongoing "trade wars"? It does seem hard to justify unprecedented monetary easing solely in terms of what have been, in many cases, only decimal point deviations of inflation from targets. And, if AME central banks have effectively changed the objective of monetary policy, what might be the eventual implications for inflation and the survival of the current, dollar based, international financial system ${ }^{66}$ At the moment, however, policymakers seem to have little appetite to discuss such fundamental issues.

\footnotetext{
${ }^{64}$ For example, Jamie Dimon has called negative rates "irrational" and has said "I would not buy debt at below zero". See Noonan (2019).

65 This issue was recently debated by 26 well known economists in a symposium called "Is a global currency war still possible?" Many felt this was a serious and dangerous possibility. See, The International Economy (2019).

${ }^{66}$ For some reflections on this see White (2019).
} 


\section{Alternative Policies to Ultra Low Interest Rates?}

Given that ultra low interest rates are a two-edged sword, the question of alternative policies immediately arises. It had become increasingly fashionable ${ }^{67}$ well before the pandemic, to suggest that fiscal expansion should be used more vigorously whenever macroeconomic stimulus seemed desirable. In recent years, both the OECD and the IMF have suggested coordinated fiscal expansion by countries having fiscal "room for maneuver", with the expansion focused on investments (infrastructure, education and skills training) likely to have positive rates of return. Somewhat in contrast, others have suggested that the fiscal expansion should take the form of government cheques sent directly to households to spend. Both schools of thought seem to favor a continuation of ultra low interest rates, thus seeming to imply that they see fiscal expansion as a complement to easy money rather than a substitute.

In response to the pandemic, and the economic costs associated with social distancing, monetary policy has been eased further. However, given the various constraints affecting monetary policy, fiscal stimulus has been used with unprecedented vigor in AMEs and even some EMEs. This has been broadly appropriate, subject to an important caveat. Fiscal expansion will support growth and tax revenues but might still raise sovereign debt ratios going forward. These ratios are already very high in many countries ${ }^{68}$ and will be pushed higher (perhaps much higher) by the negative supply shocks discussed above ${ }^{69}$ Together with the need to avoid the cumulating side effects of ultra low interest rates, these macroeconomic forces imply that interest rates and debt servicing requirements might eventually rise, and perhaps sharply.

To reduce the likelihood that this might lead to an eventual fiscal crisis, ${ }^{70}$ government borrowing should be done at increasingly long durations to lock in low rates. Governments should also commit themselves up front to pursuing medium term fiscal targets vigorously once the economy is firmly in expansionary mode again. Guidance as to the specifics of how this might be done (which taxes to raise and which expenditures/subsidies to cut) would also be welcome in reassuring markets and maintaining market access.

Both public sector and private sector debt ratios are at uncomfortably high levels in many countries. Recent experience with fiscal austerity, and recollection of Keynes' paradox of thrift, indicates this is not a near term solution. With growth likely to be impeded by the headwinds of debt and demographics, it would also be unwise to assume that we can simply grow out of any associated problems. Higher inflation might also be a solution, but it would be imprudent to suppose that this might not easily get out of control. Moreover, generating more inflation through ultra low interest rates only contributes to the undesired side effects referred to above. "Financial repression", as practiced in many countries in the aftermath of World War II, requires a

\footnotetext{
${ }^{67}$ For example, see Blanchard and Summers (2019).

${ }^{68}$ Miron (2015), using the intertemporal accounting framework suggested by Larry Kotlikoff, provides evidence that all the large sovereigns are effectively bankrupt, and by a large margin. That is, legislated promises to spend (on and off-balance sheet) significantly exceed the revenues likely to be generated by current tax legislation.

${ }^{69}$ Goodhart and Pradhan (2020) emphasize these fiscal effects, noting especially the costs to governments of dealing with ever rising rates of dementia in an aging population.

${ }^{70}$ As noted above, Sargent and Wallace (1981) provide the theory for how this process works and Bernholz (2006) provides numerous historical examples.
} 
combination of higher inflation and repressed (low) interest rates to reduce debt ratios over time. In addition to the dangers associated with each, it is doubtful in the modern world that the stringent administrative measures required for success would be politically acceptable.

If these alternative solutions to unserviceable debt requirements are not available, much more reliance will have to be put on debt restructuring. Disorderly debt defaults, without the cooperation of creditors, involve much greater costs than orderly defaults in which creditors and debtors work together. Unfortunately, recent work by the OECD (2013), the IMF (2016) and the Group of Thirty (2018) makes it clear that the laws and judicial procedures for restructuring debt continue to be highly unsatisfactory. This applies to private non-financial debt (households and corporations) in many countries and still more to private financial debt (especially banks that are too big to fail). Above all, it applies to sovereign debts where there are still no agreed upon criteria for the need to restructure, nor any international treaties to force action. Dealing with these problems is a challenge that governments should start to take on now. It is a dangerous delusion to suppose that central banks can somehow mitigate this need for action by governments. 


\section{References}

Acharya, V (2019) "Monetary easing, leveraged payouts and lack of investment" Presentation at Imperial College London, 12-13 December.

Acharya A, M Krosignani, T Eisert and C Eufinger (2020) "Zombie Credit and (Dis)Inflation: Evidence from Europe" Staff Report 944, Federal Reserve Bank of New York, New York, December.

Agarwal R and M S Kimbal (2019) "Enabling deep negative interest rates to fight recessions: a guide” IMF Working Paper 84, Washington DC, April.

Aliaj O and E Platt (2021) "Baupost's Seth Klarman compares investors to 'frogs in boiling water" Financial Times, 21 January.

Altavilla C, L Burlon, M Giannetti and S Holton (2019) “The impact of negative interest rates on banks and firms" Vox, 8 November.

Atkeson A and P Kehoe (2004) "Deflation and depression: is there an empirical link?" American Economic Review, 94(2), pp 99-103.

Bailey M J (1962) "National income and the price level” McGraw Hill, London.

Banerjee R and B Hofmann (2018) “The rise of zombie firms: causes and consequences” BIS Quarterly Bulletin, Basel, September.

Bank for International Settlements (2020) "Markets rise despite subdued economic recovery" BIS Quarterly Review, Basel, September.

Barlevy G (2019) "A theoretical model of leaning against the wind" Presentation at Imperial College London, 12-13 December 2019.

Bernholz P (2006) “Monetary regimes and history: economic and political relationships” MPG Books.

Binham C (2019) "European Banking Authority highlights bleak outlook for banks” Financial Times, 29 November.

Blanchard O (2021) “In defense of concerns over the $\$ 1.9$ trillion relief plan” Peterson Institute of International Affairs, 18 February.

Blanchard O and L S Summers (2019) "Evolution or revolution: an afterword” Vox, 13 May.

Bloomberg News Wire (2020) “America's zombie companies are multiplying and fueling new risks" Bloomberg News, 19 May.

Borio C and W White (2004) "Whither monetary and financial stability? The implications of evolving policy regimes” BIS Working Papers No 147, Basel, February. 
Borio C, E Kharroubi, C Upper and F Zampollli (2015) "Labor reallocation and productivity dynamics: financial causes, real consequences” BIS Working Papers No 534, Basel.

Borio C, M Erdem, A Filardo and B Hoffman (2015) “The costs of deflation: an historical perspective” BIS Quarterly Review, Basel, March.

Bulow J, C Reinhart, K Rogoff, and C Trebesch (2020) “The debt pandemic” Financial Development, IMF, September.

Cavallino P (2019) “The open economy ELB: Contractionary monetary easing and the trilemma" Presentation at Imperial College London, 12-13 December.

Cerra V and S C Saxena (2008) "Growth dynamics: the myth of economic recovery" American Economic Review, Vol 98 (1), pp 439-457.

Cerra V and S Saxena (2017) "Booms, crises, and recoveries: A new paradigm of the business cycle and its policy implications" IMF Working Paper 250, Washington DC, November.

Chappatta B (2021) “Bond ETF Survived 2020 Liquidity Scare: But Just Barely” Bloomberg Opinion, 4 January.

de Larosiere J (2019) “The monetary policy challenge” Centre for Financial Stability, Frankfurt, 25 November.

Doerr S (2020) “Could housing booms undermine productivity growth?” SUERF Policy Briefs No. 40, December.

Eggerston G B, R E Jeulrud and E G Wold (2017) “Are negative interest rates expansionary?" Mimeo, October.

Eggerston G B and L H Summers (2019) "Negative interest rates and the bank lending channel" Vox, 24 January.

Financial Stability Board (2017) "FSB publishes assessments of shadow banking activities and the adequacy of policy tools", Basel, 3 July.

Financial Stability Board (2020) "Global monitoring report on non-bank financial Intermediation” Basel, 16 December.

Fisher I (1933) “The debt-deflation theory of great depressions” Econometrica 1 (4) pp 337-357.

Goodhart C A E and M Pradhan (2020) “The Great Demographic Reversal” Palgrave Macmillan, London.

Grisogona A-M (2020) "How could future AI help tackle global complex problems?" Frontiers in Robotics and AI, Vol. 7, Article 50, April. 
Group of Thirty (2015) "Fundamentals of central banking: Lessons from the crisis" Washington DC, October.

Group of Thirty (2018) "Managing the next financial crisis” Washington DC, September.

Hannon H, O Issing, K Liebscher, H Schlesinger, J Stark, N Wellink, J de Larosiere and C Noyer (2019) “The Great Debate” The International Economy, Fall, pp 35-36.

International Monetary Fund (2017) “Gone with the headwinds: global productivity" IMF Staff Discussion Note 17/04.

International Monetary Fund (2019) “Global Financial Stability Report” October, Washington DC.

Keynes J M (1961) “The General Theory of Employment, Interest and Money” Macmillan and Company, London.

Koby Y and M Brunnermeir (2019) “The reversal interest rate” Presentation at Imperial College, London, 12-13 December 2019.

Hayek F A (1975) "Full employment at any price?" Occasional Paper 45, The Institute of Economic Affairs, London.

International Monetary Fund (2016) “A strategy for resolving Europe's problem loans” Staff Discussion Note, Washington DC.

Liang J N (2020) "Corporate bond market dysfunction during Covid-19 and lessons from the Fed's response” Brookings Institution, Hutchins Centre Working Paper 69, Washington DC, October.

Lynch D J (2020) “Here's one more economic problem the government's response to the virus has unleashed: Zombie firms" The Washington Post, 23 June.

Martinez-Miera D (2019) "Interest rates, market power and financial stability" Presentation at Imperial College, London, 12-13, December.

McKinsey Global Institute (2019) “Signs of stress in the Asian financial system” Global Banking Practices, July.

McWilliams J (2018 "Remarks" Fourth Annual Financial Stability Conference at the Office of Financial Research and the University of Michigan's Centre on Finance Law and Policy, Washington DC, 15 November.

Merton R (2006) “Observations on innovation in pension funds management in the impending future" Presentation at the 2005 NCREIF conference.

Minsky H P (2008) “Stabilizing an unstable economy” McGraw Hill, New York. 
Miron J (2015) “US fiscal imbalance” The Cato Institute, Washington DC, December.

Noonan L (2019) “Jamie Dimon calls negative rates irrational” Financial Times, 18 October.

OECD (2013) "Debt and macroeconomic stability” Economics Department Policy Notes, 16 January.

OECD (2017) “Confronting the zombies: Policies for productivity revival” Economic Policy paper 21, Paris.

Peek J and E S Rosengren (2005) "Unnatural selection: Perverse incentives and the allocation of credit in Japan" American Economic Review 95: 1144-66.

Reinhart C M and V R Reinhart (2010) “After the fall” In Macroeconomic Challenges: The Decade Ahead, Federal Reserve Bank of Kansas City.

Renison J and E Platt (2021) "Riskiest borrowers make up biggest share of junk bond deals since 2007” Financial Times, 15 February. Rogoff K (2016) “The curse of cash” Princeton University Press, Princeton NJ.

Sargent T J and N Wallace (1981) "Some unpleasant monetarist arithmetic" Federal Reserve bank of Minneapolis Quarterly Review, Fall, pp1-17.

Schrimpf A, H S Shin and V Sushko (2020) "Leverage and margin spirals in fixed income markets during the covid-19 crisis" BIS Bulletin, Bank for International Settlements, Basel.

Selgin G (1997) "Less than zero: The case for a falling price level in a growing economy" IEA Hobart Paper No 132, London.

Smets F (2019) "On the effectiveness of a negative interest rate policy" Presentation at Imperial College London, 12-13 December.

Smithers A (2019) "Productivity and the bonus culture" Oxford University Press, Oxford.

Stehn H and S Radde (2019) "How much could the ECB cut?" Presentation at Imperial College London, 12-13 December 2019.

Summers, L (2021) "The Biden stimulus is admirably ambitious. But it brings some big risks too" Washington Post, 4 February.

Swiss Banking Association (2019) "Negative interest rates: from emergency measure to the new normal - and back?” Zurich, October.

Tepper J (2020) "Federal Reserve has encouraged moral hazard on a grand scale" Financial Times, 12 April.

The Economist (2019) "So much rests on so few making so little” December 14-20, p 57-58. 
The International Economy (2019) "Is a global currency war still possible?" A Symposium of Views, Summer, pp 16-34.

UNCTAD (2018) "External debt sustainability and development: report of the SecretaryGeneral” Geneva, 16 July.

Volcker P with C Harper (2018) “Keeping at it "Public Affairs, New York.

White W (2006) “Is price stability enough?” BIS Working Papers No 205, Basel, April.

White W (2006) "Measured wealth, real wealth and the illusion of saving” Irving Fisher Committee Bulletin No 26, August.

White W (2016) “Ultra-easy money: digging the hole deeper?” Business Economics Vol 51, Issue 4, October. pp188-202.

White W (2019) “Are fears of a global currency war justified?” The Market: NZZ, 5 November.

White W (2020) "International financial regulation: why it still falls short" Working Paper Series, INET, August.

Woodford M (2020) "Post-pandemic monetary policy and the effective lower bound" Presentation at Conference organized by The Federal Reserve Bank of Kansas City, Jackson Hole, August. 